\title{
Correlation of Migration Processes and the Social Concept of "Home"
}

\author{
Sergey V. Mostikov* \\ University for the Humanities \\ 24a Surikova Str., Ekaterinburg, 620144, Russia
}

Received 10.03.2015, received in revised form 12.06.2015, accepted 29.06.2015

The article examines the socio-psychological causes of migration, rooted not only in economic and political sphere, but also in the parent-child relationship of future migrants. There are parallels between the change of country residence and relationship with parents.

Leaving "Home", the person is not simply looking for a more comfortable physical space, he also seeking a new "Home", which manifests itself as a particular social situation where a person feels the psychological stability and reliability. In that way, "Home" is a conceptual embodiment of hopes, needs and values of an individual, this is a "resource place" existential fullness of man's being.

Migration can be due two conditions: a psychological escape from something or an intentional jump to something. In both cases we deal with the process of subjective interpretation of past events or projecting ourselves into the future. In methodology we use existential and psychodynamic approach, the analysis of migration processes is carried out at the interdisciplinary intersection of philosophy and psychology.

There is a question about transformation of psychological identity, when a migrant changes the country. This process happens on behavioral, value, emotional and cognitive levels. A significant part of the "I-image" whichthe migrant got in his childhood at "Home" and it rooted in the language. According to this, it is inefficient and requires processing under a new social reality. Thus, the migrant has to become a "self-made man".

Keywords: migration, psychological adjustment, social philosophy, the concept of "Home", the causes of migration, the Oedipal conflict, identity, self-concept.

DOI: 10.17516/1997-1370-2015-8-9-1990-1997.

Research area: philosophy.

Introduction and statement of the problem. According to the Federal State Statistics Service, currently there is an increasing flow of Russian citizens leaving the country for permanent residence abroad. There have been similar situations already in the history of our country, the hugest increase was the mass exodus of people after the October Revolution of 1917, as well as in the critical years of the Soviet collapse. Almost all of the migratory waves in Russia turned out to be related to the fundamental frustration of social needs of the citizens: predictability of political line, social stability, respect for basic human rights. Replication of the

(c) Siberian Federal University. All rights reserved

* Corresponding author E-mail address: smostikov@ya.ru 
causes of migration processes from generation to generation during the whole century indicates serious system problems and the dysfunctional nature of the interaction within the framework of "citizen - state" system.

One of the determinants of this situation is the institutional weakness of "the civil society", which is currently unable to act as a significant agent of sociality performing the role of a safety filter against abuse of the state apparatus in relation to a particular individual, thus, as D.S. Vas'kovich rightly points out "the immigration policy of the Russian Federation since its inception till the date is based on "the catch-up" model, in response to the already existing situation" (Vas'kovich, 2009). These facts contribute to updating of these issues at both the conceptual and the practical levels of knowledge. The highlighted topic needs a closer analysis in more detail in different disciplinary areas that we propose to perform in the synthetic field of interaction of psychology and philosophy using the existential basis of personality as a foundation.

Moving to another country and the subsequent transformation of life attitudes of the migrant inevitably demonstrate the current need to address worldview objectives that throw us in the existential fields of thoughts by their ultimate bases. Migration movements of the population are not reducible only in relation to the statistical data, while psychological and philosophical issues cannot be considered only through the prism of figures and indicators, while the object of the study is human. Appealing to ontological foundations make us actively use psychodynamic and ontological methods of searching, the views of Z. Freud and M. Heidegger, as well as their followers, seem to us the most appropriate to fulfill the study of this topic.

Consideration and discussion. First of all, we would like to highlight the concept of "Home" as a psychological category that acquires a special significance in the context of values and attitudes of personality. It is not so much a country that any migrant (forced or voluntary) leaves, but their home as a set of certain psychological meanings, histories and values. Leaving "Home", they lose behavioural and social roles, i.e., a part of their personal identity, which manifests itself to the world, first of all, on the border of social interaction. "Home" is a resource state of the individual, which expands itself in a particular situation or place, so that we feel our rootedness in being, we feel calm and comfortable. The concept of "Home" is an integrated mix of communication styles, language practices, ontological certainty, stability and continuity of the past, the present and the future. Feeling at "Home" can be attributed to the peak, existential moments of life when a person feels a special unity of the external and the internal aspects of being.

Changing the usual circle of interpersonal communication inevitably questions the identity of the migrant: previous notions about themselves are already irrelevant, and the new image of the "self" has not been formed yet. To form the new "self" requires social interaction with the carriers of a new culture, but communication with them may be limited. A never-ending circle: migrants need to adapt to the new environment, but to do this it is necessary to communicate with the carriers of this culture, but in order to communicate, one should have an understanding of behavioural patterns in this cultural environment. Despite these difficulties, the majority of migrants cope with this problem, although there are those who are forced to go back to home countries. G. Deleuze provides a brilliant idea which demonstrates the importance of the external contacts and interaction: "Events that are radically different from things, are observed not in the depth but on the surface, in the dim incorporeal mist emanating from the body ... the deepest part of the body is the skin" 
(Deleuze, 1998). In the act of the social touching of the Alien we feel our identity, psychological self-concept can be manifested through the social contact, in the process of which we find social essence, esse est percipi (J. Berkeley).

Change of "Home" at the early stage iniciates the modification of behavioural acts (learning by imitation), and then on the rise, worldview components of personality are changing. At the same time, the greater the cultural confrontation between the two countries, the stronger is the seismic fracture of personality that the migrant has to overcome during assimilation in a new country. These tectonic movements of the selfconcept components induced by the plunge in a new environment, can act as a trigger mechanism to release powerful forces of the psychic world explicated both at personal-unconscious and archetypal levels. In this respect, the research of the South African psychologists Cochrane $\mathrm{R}$. and Bal S. has shown interesting results. They demonstrate an increase in the number of patients with schizophrenia among migrants (Cochrane R., Bal S., 1987), and the subsequent cross-cultural research in this area has confirmed these findings (Cantor-Graae E., Pedersen C., McNeil T., Mortensen P., 2003). It important to remember that the psychological stress caused by severe stress during the migrant's assimilation is breaking out, but can be channelized in a positive direction: employment, the expansion of the circle of friends, etc., and in a negative direction, in the latter case we observe the failure of mental functioning, autodestructive or antisocial behaviour. The sad example of Biriuliovo or collisions of migrants with police in Europe prove this fact.

The speed of the adaptation process and its qualitative indicators (the value of the stress, the sense of nostalgia, the social situation in the new country, etc.) depend both on the subjective psychological factors (readiness to change, stress resistance, peculiarities of interpersonal communication), and the objective factors such as differences between the values and personal attitudes of the migrant and the host country. As E.B. Perelygina and A.I. Dontsov rightly note, "Social-psychological parameters of social interaction largely depend on the type of culture, as well as certain behavioural strategies related to national, mental traits" (Dontsov A., Perelygina E., 2011). Main difficulties in psychological and cultural assimilation process are observed among the migrants from the so-called traditional societies, where the continuity, the connection with the history of their family and country are important. The image of Motherland, family and home is so powerful that it overshadows other aspects of life and as a result forces migrants to restrict their circle of contacts to only countrymen, to rarely speak the language of the host country, to live in the "national districts". In the longterm perspective, this strategy becomes a failure, because person is in the comfort zone and is not going to leave it. To find a new "Home" they will have to leave the past behind.

The notion of "Home" is a key element in the psychological system of coordinates of any migrant. The very act of migration, moving to another place intensifies this construct as a valuepersonal and vital understanding. In psychological counseling there is even a corresponding notion, "a place of power", as the focus of mental resources of the individual, the acquisition of which allows the person to perceive themselves holistic and rooted in existence, this idea partly coincides with Heidegger's "here is being" as endowed with higher meanings that go beyond the frame of everyday life.

"Home" is not a point in space, but the specific structure of social interaction of personality that allows us to treat this type of communication and position ourselves in the culture as its native, comfortable and safe. In this context, the 
interpretation of O.Iu. Zotova is quite interesting: "As a result of long-term interaction and on the basis of common interests and aspirations, such social-psychological community appears that is characterized by mutual understanding, solidarity and trust"(Zotova O., 2012). Thus, communication techniques play the key role in establishing and maintaining social compatibility of being. At the conceptual level, the interaction of the migrant with the citizens of the host country is presented as a dialogue of cultures mediated through the consciousness of personality, i.e. two cultures, two countries with their own traditions, values and objectives meet during the communicative act. During this contact, the migrant is expanding his/her ideological horizon, identifies new roleplays, learns to think differently. Introjecting the aspects of another culture determined at different levels (behavioural, cognitive, emotional) the person transforms the image of the originally foreign country into the image of "Home". Initially, this process is formalized only in the act, but is further assigned and becomes one's own, personal and meaningful conscious choice. If we compare this situation with the animal world, only turtles and snails bear their houses with them, man has his "Home" inside himself.

Individual features of the personal stories of migrants impose their specific imprint on the process of adaptation, in connection with which let us denote key moments that push people to change "Home":

1. Refusal or rejection of "Home". Due to intrapsychic features formed in childhood, man tries to escape from what can cause inner psychic pain. The migrant is not moving somewhere, but is running away from something. He commits in the external space something that he/she wants to do in the internal personal space. "Home" is perceived as a source of painful memories and traumatic events. A striking example of such a rejection and escape from the past can be the life of I.V. Stalin's daughter, Svetlana Alliluyeva, who not only left the USSR, but refused to speak her language. Even after her father's death she would write about him: "He died, but his shadow continues to stand over all of us, and very often continues to tell us, and very often we act on his decree" (Alliluyeva S., 1989). This example shows us the author's intrapersonal struggle with her father, the effect of the hidden psychological motives that are committed in the act of giving up "Home" and the past.

Thus, the migrant starts to run away from himself/herself, rejecting the past. M. Heidegger perfectly describes this condition: "Such comfort in one's improper being incites, but not to the stagnation and inactivity, but drives into precipitousness of "actions". Being-fallen into the 'world' does not now somehow come to rest" (Heidegger M., 2006). Social activity in this case, helps to get rid of and forget oneself in the act of running away.

Such a situation may also be considered, through the prism of psychoanalytical matrix as ambivalence in terms of the family system. The inner child of the migrant searches in the image of the host country an ideal parent, or another option, a classic Oedipal triangle with the rejection of one country and the idea of undivided and devoted love for the other takes place, thereby there is externalization of intrapersonal conflict and taking off the projective formations into the environment. Of course, these mental processes refract the course of social and cultural adaptation of migrants, and may become an additional factor reinforcing the stress of personality.

It is important to remember that all childhood memories are forever encoded in the native language. The image of the "Home" of childhood is impossible to authentically translate into another language paradigm without losing important, existential aspects of personal history. No matter how successfully the migrant runs away from the 
past, or rejected their first "Home" and homeland, a part of their mental constructs will always remain rooted in their native "language as in the house of Being" (Heidegger). It is noteworthy that many cultures reveal the semantic similarity of "parents" and "Homeland". For example, "otchestvo" and "otchizna", "Rodina" and "rodnia”, "otchii dom", “otechestvo", “"'Rodinamat" in the Russian language or "fatherland, motherland, homeland" in the English language. What exists in the language is also presented in thoughts and social activity of the subject. Relation to the family is related with the attitude to the Homeland. Herewith, we see quite a large variation in the behaviour of migrants: rejection of using patronymic, changing endings of many Russian surnames from "-ov" to "-of", or even a complete change of name. Obviously, these processes include a combination of factors: psychological, philosophical, social, linguistic, etc.

\section{Rejection of "Home" as a simultaneous}

process. Changing our behavioural strategies, we are not only moving away from "Home" changing it to something different, but "Home" also becomes distant. Migrants are forced "to put their native culture into oblivion" with the purpose of more successful secondary socialization in the home country, but at the same time native culture forgets the carrier that left it. The memory and consciousness of the individual, preserves the culture of their first motherland as static, "mummified", recorded at the time of the move, and therefore does not keep its features of a dynamic, changeable public formation (which is an essential feature of living and authentic culture). Losing the connection with the homeland, migrants can only have the connection with the image of the motherland through their memories, thus, in accordance with the laws of memory, the image begins to live independently: transforming and enduring changes. The latter frequently occur in a positive direction (especially when there are difficulties in adaptation in the second homeland), in everyday life it reveals itself through the act of nostalgia and the sense of missing the first homeland. Not finding the rootedness here-andnow, the migrant is forced to seek support in the abandoned past. The migrant is almost always in the marginal social position of an alien in a foreign country. Concepts of social-psychological alienation, unfortunately, have been relatively little worked through in the modern block of the humanities knowledge. Depending on the individual psychological characteristics, there are different cognitive patterns in understanding and explaining their otherness in relation to the general population of the residence country. These mental patterns will induce appropriate social actions and deeds.

In our view, it is important to determine a number of practice-oriented aspects of psychological assistance to migrants in a difficult situation: it is necessary to recognize the psychoemotional stress of the migrant as standard and natural in the current situation. An alien always remains an alien; there are differences even among the closest people. It is impossible to be a copy of someone else, but we can move towards close and emotionally rich partner relationships. For example, if we talk about differences, our interpersonal relations will become distant, but if we speak and develop what binds us together, we will become closer. Acceptation and humility that we are all different (by skin colour, gender, nationality, religion, etc.) can be a resource to our communication, we can cultivate our closeness and learn new things about ourselves and others through it. Positive reframing of social reality helps to improve the psycho-emotional state of the individual.

In addition to the theme of alienation, it is necessary to note the fact of how migrants are treated in their first homeland, while it has an 
impact on the individual. Cinzia Solari rightly points out that in every culture there are different representations of fellow citizens, who have left the country and have become foreigners. For example, Mexico and Vietnam families are proud of migrants, and in the Ukraine they are treated scornfully (Cinzia Solari, 2014). For Russia it is more typical to be proud of the country (perhaps sometimes ostentatious), but at the same time, there is a special state of mind that is often transmitted through $\phi$ concise term "the suitcase mood".

\section{Existential migration as a search for}

"Home"». In contrast to the first scenario, when a traumatic past pushes a person into the future, in this case, there is an orientation and internal intention to find once lost or never achieved idealized object. Obviously, this is rooted not only in the individual past, but also in archetypal representations of the humanity (search of the lost paradise, the geographic correlate of the Garden of Eden, etc.). In terms of transactional analysis by Eric Berne, this behaviour can be differentiated as a "heroic" scenario: to find a "home", which will not just become personally significant, but is also explicated through the modes of "Home-being", a certain transcendent beyond the personal psychic individuality. This scenario is characterized by a search for "home", country or culture in which the migrant will have a feeling that he/ she has found his "home" or homeland. It is the need for rootedness, belonging to something, beyond personal existence.

In relation to this issue, a lot of modern research, especially Western research in the field of social psychology and migration studies, despite the philosophical and humanistic approach that outlines the need for self-realization of the individual and the implementation of his/her Dasein, is characterized by two other vectors of thought:
The first approach can be roughly defined in the framework of psychotherapy through the term "compulsive migration" (Susan G. Keortge, Gina M. Formea, Lee G. Sternberger, 1996), as a constant urge to change the country and nationality (it should be distinguished from dromomania as a symptomatic fragment in the syndromic range of mental disorders). Herewith, the psyche has a clear adaptive system that helps to fit in quite a large range of cultural regions, and, in general, not only maintains a high level of performance, but in some respect proves to be even more efficient than the average population figures. C. Lindner in the research results gives reference to the interviewees who have been citizens of 5-9 countries within 10-15 years (Lindner C., 2013), even the cynic Diogenes of Sinope can envy such cosmopolitanism. Research in the field of "compulsive migration" tries to draw a demarcation line between the psychological problems of the individual and social specificity of the "creative class" (R. Florida), characterized by a high degree of mobility in the conditions of the neoliberal world order. It is now possible to observe the erosion of the concept of citizen, Glick, Schiller N. et all even introduce a term "trans-nationality" (Glick, Shiller N, Basch L, Blanc-Szanton C, 1999), highlighting the loss of the previous meaning of the definitions fatherland, citizen, homeland. Under these circumstances, what Russian citizens treat as migration (with all its difficulties), the residents of Europe or the United States regard as relocation and change of the residence place. This peculiarity is reflected in the topics of international socio-psychological research, where the concept of adaptation is used mainly for the residents of the Third World countries.

The second aspect of this issue can be explicated in terms of psychodynamic thinking as contamination, "a mixture of early object relations resulting from frustration and early 
psychological gap: a child and a person in charge of the primary care" (Balint M., 1959; Grinberg L. Grinberg R., 1989). But unlike the situation with the rejection of "Home", the following positive goals are formed herewith:

- the desire to find the perfect "Home", which will be safe and secure;

- the desire to meet the image of a good parent (in the case of the oedipal conflict), in the face of a good and hospitable country.

The shift of the meaning in a particular case will be determined by a personal history of an individual, taking into account psychological factors and socio-cultural context of each of the two countries.

\section{Conclusions}

1. Architectonics of socio-psychological studies of migration processes is quite a wide semantic field, not reducible to the issues of psychological adaptation and social arrangement, it also incorporates value-semantic component of personality.

2. Migration in the era of "hyper-realism of the quartic simulacra" (Baudrillard J., 2000) can be represented as a search for the terminal reason of human existence and the need for rootedness of individual being.

3. Migration processes can be determined not only by socio-political situation in the country, but also by peculiarities of young children's personal development, their relationships with parent.

\section{References}

1. Alliluyeva S.I. Twenty letters to a friend (Dvadtsat' pisem k drugu). Moscow, Kniga, 1989. p. 4.

2. Balint M. Thrills and Regressions. New York. International University Press, 1959,p. 183.

3. Baudrillard J. l'échange symbolique et la mort (Simvolicheskii obmen i smert'). Moscow, Dobrosvet, 2000. p. 113.

4. Cantor-Graae E., Pedersen C., McNeil T., Mortensen P. (2003).Migration as a risk factor for schizophrenia: a Danish population-based cohort study. The British Journal of Psychiatry.Feb (182),117-122.

5. Cinzia Solari (2014). Prostitutes and 'Defectors: How the Ukrainian State Constructs Women Emigrants to Italy and the USA. Journal of Ethnic and Migration Studies Vol. 40, No. 11, $1817-1835$.

6. Cochrane R., Bal S. (1987). Migration and schizophrenia: an examination of five hypotheses. SocPsychiatry.New York.181-191.

7. Deleuze G. Loguque du sens (Logika smysla). Yekaterinburg, Delovaia kniga, 1998. p. 26.

8. Dontsov A. I., Perelygina E.B. (2011) Security issues of communicative strategies. (Problemy bezopasnosti kommunikativnykh strategii). Bulletin of Moscow University, 14(4),p. 30.

9. Federal'naia sluzhba gosudarstvennoi statistiki(Federal service of state statistics) Available at: http://www.gks.ru/wps/wcm/connect/rosstat_main/rosstat/ru/statistics/population/ demography/\# (2014)

10. Glick Shiller N, Basch L, Blanc-Szanton C. Towards a Transnational Perspective on Migration: Race, Class, and NationalismReconsidered. New York. The New York Academy of Sciences, 1999. pp. 1-24.

11. Grinberg L. Grinberg R. Psychoanalytic Perspectives on Migration and Exile. New Haven, CT: Yale University Press. 1989, p. 259. 
12. Heidegger M. Sein und Zeit (Bytie i vremia). Translation by V. Bibikhin. Kharkiv, Folio, 2003. p. 206.

13. Lindner Carol Neuschul. Are We There Yet? Understandings of Home Among Compulsive Migrants. The Asian Conference on Cultural Studies.Official Conference Proceedings. Osaka. 2013.p. 406.

14. Susan G. Keortge, Gina M. Formea, Lee G. Sternberger. (1996). Cultural context, obsessivecompulsive disorder symptoms, and cognitions: a preliminary study of three Turkish samples living in different countries. Behaviour Research and Therapy. Volume 34, Issue 2, February,pp. 163-173.

15. Vaskovich D.S. The immigration policy of the Russian Federation - the dynamics of changes (Immigratsionnaia politika Rossiiskoi Federatsii, dinamika izmenenii). Moscow, Publisher HSE, 2009. p.13

16. Zotova O. Iu. (2012) Technology communicative interaction to ensure the security and trust. (Technology communicative interaction to ensure the security and trust). Nacional'nyi psikhologicheskii zhurnal,1(7), 89 .

\title{
Соотношение миграционных процессов и социальной концепции «Дома»
}

\author{
С.В. Мостиков \\ Гуманитарный университет \\ Россия, 620144, Екатеринбург, Сурикова 24а
}

\begin{abstract}
В статье рассматриваются сочиально-психологические причины миграции, которые коренятся не только в экономико-политический сфере, но ив том числе в детско-родительских отношениях будущего мигранта. Проводятся параллели между сменой страны проживания и отношениями с родителями.

Покидая Родину, личность не просто ищет более комфортное физическое пространство, но стремится обрести новый «Дом», который являет себя как особая соииальная ситуаиия, где личность ощущает психологическую стабильность и надежность. Таким образом, «Дом»это кониептуальное воплощение надежд, потребностей и иенностей индивида, это «ресурсное место», экзистенциальная наполненность личностного бытия.

Прочесс миграиии может осуществляться из двух состояний: психологического бегства от чего-то либо как интенщиональный бросок к чему-либо. В обоих случаях мы имеем дело с процессом субъективного истолкования внешних событий либо в прошлом, либо с проецированием в будущее. В качестве методологической матрищы в статье используется экзистенциально-психодинамический подход, анализ миграционных процессов выполнен в силовом поле междисциплинарного пересечения философии и психологии.

Смена страны проживания ставить перед мигрантом вопрос трансформации психологической идентичности. Этот процесс будет проходить на поведенческом, ценностном, эмоциональном и когнитивном уровнях. Значительная часть образа-Я, сформировавшаяся у мигранта в детстве на Родине и укорененная в языке, оказывается малоэффективной и требует переработки под новую соииальную реальность. Таким образом, мигрант вынужден «делать себя своими руками».
\end{abstract}

Ключевые слова: миграџия, психологическая адаптаџия, соџиальная философия, кониепџия "Дома», причины миграчии, эдипальный конфликт, идентичность, Я-конщепщия.

Научная спеииальность: 09.00.00 - философские науки. 